University of Pennsylvania Carey Law School

Penn Law: Legal Scholarship Repository

Faculty Scholarship at Penn Law

2018

\title{
A Brief Summary and Critique of Criminal Liability Rules for Intoxicated Conduct
}

Paul H. Robinson

University of Pennsylvania Carey Law School

Follow this and additional works at: https://scholarship.law.upenn.edu/faculty_scholarship

Part of the Comparative and Foreign Law Commons, Criminal Law Commons, Criminology Commons, Criminology and Criminal Justice Commons, Jurisprudence Commons, Legal Theory Commons, Public Law and Legal Theory Commons, and the Substance Abuse and Addiction Commons

\section{Repository Citation}

Robinson, Paul H., "A Brief Summary and Critique of Criminal Liability Rules for Intoxicated Conduct" (2018). Faculty Scholarship at Penn Law. 1980.

https://scholarship.law.upenn.edu/faculty_scholarship/1980

This Article is brought to you for free and open access by Penn Law: Legal Scholarship Repository. It has been accepted for inclusion in Faculty Scholarship at Penn Law by an authorized administrator of Penn Law: Legal Scholarship Repository. For more information, please contact PennlawIR@law.upenn.edu. 


\title{
A Brief Summary and Critique of Criminal Liability Rules for Intoxicated Conduct
}

Paul H. Robinson ${ }^{1}$

\begin{abstract}
This essay provides an overview of the legal issues relating to intoxication, including the effect of voluntary intoxication in imputing to an offender a required offense culpable state of mind that he may not actually have had at the time of the offense; the effect of involuntary intoxication in providing a defense by negating a required offense culpability element or by satisfying the conditions of a general excuse; the legal effect of alcoholism or addiction in rendering intoxication involuntary; and the limitation on using alcoholism or addiction in this way if the offender can be judged to be reasonably responsible for creating his own addiction. It notes some of the differences between the US and UK approaches on some issues.
\end{abstract}

I. The Possible Legal Effects of Intoxication Itself - Involuntary Intoxication

II. Voluntary Intoxication

III. Problems with the Traditional Voluntary Intoxication Doctrine that "Imputes" Recklessness

IV. Fixing the Voluntary Intoxication Rule - A Proposed T1-T2 Analysis

V. Alcoholism and Addiction

VI. Conclusion

This essay offers an overview of the legal and conceptual issues relating to intoxication, criticisms of current criminal law, and finally a proposal for providing a just assessment of criminal liability for intoxicated conduct.

It focuses first on the issue of the possible legal effects of intoxication itself. That is, if one considers the case in which there is no complicating issue of the intoxication being voluntary, what legal effect, if any, does the actor's intoxication have? Second, it takes up the complications that come when a person voluntarily intoxicates him or herself. How does this change the legal effect of the intoxication? Finally, it considers the issue of addiction. Does a person's addiction have the legal effect of converting his apparently voluntary intoxication into involuntary intoxication, thereby giving greater opportunity for mitigation or excuse?

\section{The Possible Legal Effects of Intoxication Itself - Involuntary Intoxication}

Assume somebody has put something in your drink that, unknown to you, causes intoxication during which you engage in reckless conduct that hurts someone else. You are

\footnotetext{
${ }^{1}$ Colin S. Diver Professor of Law, University of Pennsylvania. This essay is based upon an address given at the Intoxication, Addiction and the Criminal Law Conference at the University of Sussex in January of 2018.
} 
flailing around dancing wildly in a crowded room and end up smashing someone in the face, cutting her badly.

You are charged with an offense like reckless wounding, which requires proof that you caused the injury and knew at the time that your conduct risked causing the injury. Does the person's intoxication (involuntary in this instance) affect his criminal liability and, if so, how?

No Effect. In some instances the intoxication may have no legal effect whatever. It can have a legal effect only if it has certain specific physiological effects on you at the time of your offense. And, frankly, having a legally significant effect is very much the exception rather than the rule. The effect of the involuntary intoxication must be to "negate" a required culpability element. If, despite your intoxication, you were still aware that your conduct created a risk of injuring others at the time of the offense, then you will be fully liable for the offense. ${ }^{2}$

Negating Offense Element. On the other hand, on these facts it might actually be the case that, because of your intoxication, you were not aware at the time of the offense that your conduct created a risk of injury to others. If this is the case, then your intoxication will provide a defense to the reckless wounding charge by making it impossible for the prosecution to prove all the required culpability elements of the offense. ${ }^{3}$ As we shall see, if your intoxication in such a case had been voluntary, then you would get no such defense.

Involuntary Intoxication as a General Excuse Defense. Involuntary intoxication ought to also provide a defense, even if it does not "negate" required offense element, if it causes some significant cognitive or control dysfunction so severe as to render the offender unaware of the nature of his conduct or unable to control it. In other words, if the effect of the involuntary intoxication is similar to the effects that might give an offender an insanity defense if the effects had been caused by mental illness, then the offender ought to get a general excuse defense. ${ }^{4}$

For example, assume involuntary gross intoxication led the defendant to engage in conduct which might normally interest him - such as having intercourse with underage young men - but which he would normally have no difficulty restraining his impulses and internal desires. If he gives in after being involuntarily intoxicated, one would want to at the very least inquire into the extent of loss of control caused by the involuntary intoxication. The general rule ought to be, as it is in the ALI's Model Penal Code section 2.08(4), ${ }^{5}$ an involuntarily intoxicated offender ought to be eligible for a general excuse under the same conditions as he would be if his resulting mental dysfunction have been caused by mental illness under the insanity defense.

\section{Voluntary Intoxication}

Most modern criminal codes have a fairly detailed definition of what qualifies as "voluntary" intoxication, as in Model Penal Code section 2.08(5):

\footnotetext{
2 See Paul H. Robinson et al., Criminal Law (2d edn, Wolters Kluwer, 2012) 385.

${ }^{3}$ See Card et al., Criminal Law (17 edn.) at paragraph 18.74 (citing Kingston).

${ }^{4}$ See Robinson et al., Criminal Law (n 2) 384.

${ }^{5} \mathrm{MPC}$ section 2.08 reads:

(4) Intoxication which (a) is not self-induced or (b) is pathological is an affirmative defense if by reason of such intoxication the actor at the time of his conduct lacks substantial capacity either to appreciate its criminality [wrongfulness] or to conform his conduct to the requirements of law.
} 
Intoxication may be involuntary because the person ingested the intoxicating substance without knowing its intoxicating effects, but without even knowing that they were ingesting it, or the intoxication may be involuntary because the intoxicating effects were so dramatically greater than could reasonably be have been expected (pathological intoxication).

How does the legal effect of intoxication change if a person voluntarily intoxicates himself or herself?

Under the American approach, such as in ALI's Model Penal Code section 2.08(2), ${ }^{6}$ an offender's absence of a required culpability element, which he would have had had he been sober, does not give him a defense to that offense, as it did for involuntary intoxication (as just described). Instead, in the hypothetical above, the legal doctrine "imputes" to him the missing recklessness as to wounding another - on the grounds that he would have been aware of the risk had he been sober and he is the one who chose to intoxicate himself, thus causing his unawareness of the risk. The same is true for intoxication that causes him to be unaware of a risk about some circumstance that makes his conduct criminal, such as the consent of his sexual partner or the fact that property he is taking belongs to another. ${ }^{7}$

The UK has an analogous rule, ${ }^{8}$ although phrased in terms of specific intent and general/basic intent: voluntary intoxication is allowed to negate a specific intent (as is required for murder, for example) but not allowed to negate a general/basic intent (such as required for manslaughter). This used to be the common law rule in the United States but 50 years ago most of the 51 American criminal codes dropped the specific intent-general intent distinction as being too vague and unworkable, adopting instead the current rule described above, in which voluntary intoxication is allowed to negate culpability levels of purposeful or knowing but not the culpability level of recklessness. There is some evidence that the general-specific intent distinction in UK law has evolved into essentially the US distinction between offenses of intention versus recklessness. ${ }^{9}$

\section{Problems with the Traditional Voluntary Intoxication Doctrine that "Imputes" Recklessness}

This treatment of voluntary intoxication - as a doctrine imputing recklessness as caused by the intoxication - does work to roughly approximate an offender's moral blameworthiness in many everyday cases, which probably explains how this came to be the criminal law rule. But a closer examination reveals its weaknesses. It can create errors in both directions: imposing more liability than deserved in some cases and less liability than deserved in others.

Consider a hypothetical to illustrate the errors: Sharon and Buff are good friends who work together in the same office. Sharon despises Buff's live-in boyfriend Peter who she thinks

\footnotetext{
${ }^{6}$ Model Penal Code section 2.08 (2) reads: When recklessness establishes an element of the offense, if the actor, due to self-induced intoxication, is unaware of a risk of which he would have been aware had he been sober, such unawareness is immaterial.

${ }^{7}$ See Robinson et al. (n 2) 207.

${ }^{8}$ See Director of Public Prosecutions v. Majewski [1976] 2 All E.R.

9 See, e.g. Card et al. (n 3) at paragraph 18.63. (calling this the "best definition" of the general intent specific intent distinction).
} 
leeches off Buff while supposedly writing the great British novel. Sharon's jealousy and anger against Peter bring her to the point where she decides she wants to kill him. Knowing that she gets violent against those she dislikes when she is intoxicated, she plans on getting grossly intoxicated with Buff, hoping that they will end up back at Buff's apartment where Peter is living. Buff has little experience with alcohol and no experience with drugs. When she and Sharon go out to the pub, Buff orders only a glass of white wine, but Sharon slips a capsule into the glass, telling Buff that it will help loosen her up. Both are soon wildly intoxicated. They return to Buff's apartment, as Sharon had hoped, find Peter sleeping, and stuff the pages of his great British novel in his mouth unaware that he is gagging to death. What criminal liability for Buff? For Sharon?

Buff will have recklessness imputed to her because she voluntarily intoxicated herself and she will be liable for manslaughter (reckless homicide). (She intentionally drank the white wine with the drug that Sharon had put in it, and at least should have been aware of a substantial risk that it would intoxicate her.) But this overpunishes Buff. She may have been at best negligent as to becoming intoxicated but this minor culpability hardly stands as an adequate basis to impute to her the recklessness as to causing Peter's death.

Like Buff, Sharon, at the time of the killing, had no intention or recklessness as to causing Peter's death but she too will have recklessness as to causing Peter's death imputed to her. But this underpunishes Sharon, because Peter's death was the ultimate goal of her larger grand scheme. She ought to be punished as a murderer. ${ }^{10}$

\section{Fixing the Voluntary Intoxication Rule - A Proposed T1-T2 Analysis}

The Law Commission proposed a reform of the law governing voluntary intoxication in its 1993 Consultation Paper, but the proposal was flawed, in my view, and in fact was never implemented. ${ }^{11}$ Let me suggest a different approach that I think avoids the complications and somewhat more elegantly approximates the way in which ordinary people think about blameworthiness in these situations - indeed there are empirical studies that show this shared community view. ${ }^{12}$

The way to avoid these inaccuracies in the voluntary intoxication rules - producing too little liability in some cases and too much in others - is to focus not on the culpability of the offender at the time of the offense but rather on the culpability of the offender as to committing the offense at the time she becomes intoxicated.

This might be called the "T1-T2 analysis": instead of focusing on the actor's offense culpability at $\mathrm{T} 2$, the time of the conduct constituting the offense, such as stuffing pages into Peter's mouth, focus instead upon the actor's culpability as to the offense at T1, the time of getting intoxicated. If an actor like Buff drinks a glass of wine at T1 with no expectation at all

\footnotetext{
10 Under UK law, Sharon's case might be compared to the "Dutch courage" rule postulated by Lord Denning in Gallagher. (See Card et al. (n 3) at paragraph 18.72.) On the other hand, Sharon is drinking not to give her Dutch courage but rather as a plan to create the circumstances in which she will hopefully kill Peter while her mind is entirely obliterated by drink. She is not getting herself courage but rather oblivion. If Gallagher can be interpreted to support full murder liability for Sharon, then that would be a good development from my point of view, for it would support the T1-T2 analysis that I suggest below.

11 The proposal would have allowed the admission of evidence that voluntary intoxication negated any mens rea but would also create an offense of criminal intoxication - which ended up being a very complicated and unsatisfactory business. See Card et al. (n 3) at paragraph 18.82.

${ }^{12}$ See Paul H. Robinson, Intuitions of Justice and the Utility of Desert (Oxford University Press, 2013) 318-326.
} 
that she might be risking injury to another, then she ought to have no criminal liability for a subsequent offense at T2 (assuming she doesn't have the culpability required for the offense at T2). On the other hand, if she drinks at T1 with the intention of ultimately killing another at T2, as Sharon did, then she ought to have murder liability. In the more common case, if she drinks at T1 knowing that she is creating a risk of injury to others - perhaps because she knows that her only way of getting home is by driving her car on a public highway which would endanger others - then she should be liable for reckless wounding at T2 if such occurs.

To summarize, then, I would propose a liability analysis in two steps:

1. Ask: at T2 (while stuffing pages into sleeping Peter's mouth) did the defendant have the culpability required for the offense (despite her intoxication)? If so, then she is liable for the offense. That is, she would be liable for whatever degree of homicide, if any, for which she satisfied the culpability requirements at the time of the stuffing - murder, manslaughter, or negligent homicide.

2. Ask: at T1 (the time of becoming intoxicated) did the defendant have the culpability required for the offense? If so, then she is liable for whatever degree of homicide her culpability level suggests.

Notice that this liability assessment does not require any kind of imputation to the defendant of a culpable state of mind that she does not have - and thereby avoids the difficult problem of knowing exactly what culpability to impute upon what culpability as to becoming intoxicated. Further, it has the advantage of producing a degree of liability that matches the defendant's degree of culpability with regard to the offense, not the kind of rough approximation with inevitable errors that we find in the current doctrine.

Thus, the grand-scheming Sharons of the world get murder liability while the naïve Buffs of the world get no homicide liability or at most only liability for some offense of negligent endangerment, if any such offense exists (which in most places it does not).

It is widely understood that intoxicating oneself creates certain risks to others but the extent of those risks and the extent of a drinker's or drug user's awareness of them varies with the person, the situation, the intoxicant, their intoxication history and experience, etc. A full and fair assessment of a person's blameworthiness for a resulting harm done while intoxicated depends upon examining all of these factors at T1 - rather than assuming, as the current doctrine does, that any voluntary intoxication has the blameworthiness equivalent to that of reckless homicide.

Still further, the empirical studies make clear that this doctrinal approach better tracks the ordinary person's intuitions of justice about the voluntary intoxication situations. ${ }^{13}$ And this convergence of community views and legal doctrine can help enhance the criminal law's reputation for being just, rather than undermining it as current doctrine sometimes does. And this convergence of legal and community views enhancing the criminal law's moral credibility with the community has the effect of enhancing its crime-control effectiveness. ${ }^{14}$

Finally, note that the T1-T2 analysis proposed here is not an entirely novel form of criminal law analysis. Indeed, it is exactly the doctrinal analysis we use in complicity cases where a person causes an innocent or irresponsible person to commit an offense. Under traditional rules in such cases, the defendant's culpability at T1, in causing the innocent or irresponsible person to commit the offense at T2, determines that person's level of liability for

\footnotetext{
${ }^{13}$ See Robinson, Intuitions of Justice (n 12) 318-326.

${ }^{14}$ See id. at chs. 9 and 10.
} 
the offense. When a person drugs another person at T1 - or applies duress, or manipulates an insane person, or a person suffering any number of other conditions of excuse - in order to cause them to commit an offense at T2, the manipulator is liable for that T2 offense at the liability level consistent with their culpability level at T1 as to causing the offense. This is the existing legal doctrine. ${ }^{15}$

Why should the analysis be any different when the person who is drugged to commit the offense is the person himself rather than someone else? Such a self-intoxication case is stronger, not weaker, than the case of intoxicating a stranger. When the person intoxicates himself at T1, rather than another person, he ought to be liable for the T2 offense based on his culpability level as to causing the offense when he intoxicated himself at T1.

\section{Alcoholism and Addiction}

The issue of alcoholism or addiction becomes legally relevant when it is used to argue that an actor's intoxication should be treated under the exculpatory rules governing involuntary intoxication (the first topic above) rather than treated under the inculpatory rules governing voluntary intoxication (the second topic above).

When can addiction qualify the defendant's intoxication as involuntary? It is not enough to be addicted. (Just as it is not enough to be mentally ill to automatically qualify for an insanity defense.) In each instance, the law must ask: what exactly were the real world effects of the addiction in compelling a person to become intoxicated? Not every instance of addiction will be so powerful and overwhelming in its effect as to qualify the intoxication to be treated as being involuntary. ${ }^{16}$

Even if the addiction creates some degree of desire and coercion, the law may expect the offender to resist these forces. In other cases, however, the compulsion may be so overwhelming that it is simply not reasonable to expect that the offender could resist. This is the same continuum of compulsion that the law is presented with by the duress excuse. In language commonly found in American criminal codes, the offender can get the excuse only if "a reasonable person in the actor's situation could not reasonably have been expected to have resisted the coercion." 17

One additional problem exists when evaluating a person's blameworthiness in addiction cases: the general principle of general defenses is that a person should not benefit from an excuse defense where he himself has brought about the conditions of that defense. Where a person puts himself in a situation where he knows or knowingly risks being compelled to commit an offense under duress, for example, he cannot claim successfully claim a duress defense. ${ }^{18}$

Similarly, the person who ingests intoxicating substances knowing that they will become or risk becoming an addict similarly will have difficulty claiming addiction as a defense to voluntary intoxication. On the other hand, a criminal law committed to punishing only where

\footnotetext{
${ }^{15}$ Model Penal Code $\$ 2.06(2)(a)$.

${ }^{16}$ See Robinson et al., Criminal Law (n 2) 385.

${ }^{17}$ Model Penal Code $§ 2.09(1)$.

${ }^{18}$ See, e.g., Model Penal Code $\$ 2.09(2)$. See also R v. Fitzpatrick [1977] NILR 20 (denying the duress defense where the defendant voluntarily joined the IRA knowing that they sometimes did such things as coercing members to commit offenses).
} 
there is true blameworthiness must keep open the possibility that a situation could arise in which an offender is not responsible for his own addiction.

\section{Conclusion}

In addition to summarizing much of the criminal law governing intoxicated conduct, this essay has proposed a number of reforms and clarifications of current law. First, it ought to be made clear in UK law that involuntary intoxication should provide a general defense whenever such intoxication causes the kind of excusing conditions that would exculpate a defendant under an insanity defense. An offender is no more responsible for causing their own intoxication in such cases than they are responsible in causing their own mental illness, thus there exists no justification for denying the general excuse.

Most importantly, the essay urges that criminal liability for voluntary intoxication be based upon the proposed T1-T2 analysis, where the focus is the offender's culpability toward committing the offense at the time of becoming intoxicated (T1), rather than current doctrine's use of the actor's decision to become intoxicated to justify imputation to the actor of the culpability required for an offense, even, for example, the recklessness as to causing death required for manslaughter. Getting intoxicated, often an entirely lawful activity, simply does not have the moral blameworthiness equivalent to creating a risk of death to another person.

If criminal law is to earn the moral credibility with the community that will allow it to harness the powerful forces of social influence and internalized norms, it must work harder to have its legal doctrine capture the full nuance of the community's judgments of justice. 